\title{
The effect of synthetic gestagens on progesterone formation in vitro in human placenta of early pregnancy
}

\author{
A. Saure, T. Teräväinen and O. Karjalainen \\ Departments of Medical Biology and Obstetrics and Gynaecology, \\ University of Helsinki, Finland
}

\begin{abstract}
Summary. Villous tissue from 26 placentae of 7-17 weeks was incubated with radioactive pregnenolone alone and with pregnenolone in the presence of progesterone and 9 synthetic gestagenic steroids and the progesterone formation was measured after $30 \mathrm{~min}$. When progesterone was present in a concentration of 31 or $310 \mu \mathrm{mol} / \mathrm{l}$ the conversion rate of labelled pregnenolone to progesterone was reduced to 88.6 and $82.2 \%$ of that of the respective control incubations. Dydrogesterone, allyloestrenol, lynoestrenol and norethynodrel under similar conditions did not inhibit the formation of progesterone. The inhibitory effects of megoestrol acetate, medroxyprogesterone acetate and norgestrel were close to that of progesterone. Norethisterone and methyloestrenolone were the most effective inhibitors of progesterone formation: when incubated in an equimolar concentration $(35 \mu \mathrm{mol} / \mathrm{l})$ with pregnenolone $(50 \mu \mathrm{g})$ the progesterone formation was reduced to $60 \cdot 0-62 \cdot 7 \%$ and $29 \cdot 1-34 \cdot 0 \%$ respectively of that of the respective control experiments.
\end{abstract}

\section{Introduction}

It has been shown that synthetic gestagenic steroids inhibit progesterone synthesis in the human cyclic corpus luteum in vivo (Johansson, 1971; Collins et al., 1974; Lehmann, Just-Nastansky, Behrendt, Czygan \& Bettendorf, 1974) and in vitro (Mukherjee, Wright \& Davidson, 1972) and in the corpus luteum of pregnancy (7-14 weeks) in vitro (Saure, Karjalainen \& Teräväinen, 1976). At this stage of pregnancy, however, the placenta is synthesizing increasing amounts of progesterone: the transference of progesterone production from the the corpus luteum to the placenta is well advanced during the 7th week and the placental production of progesterone becomes progressively dominant from the 8th week onwards (Csapo, Pulkkinen, Ruttner, Sauvage \& Wiest, 1972). It has been estimated that at 8-9 weeks of pregnancy about half of the circulating progesterone is produced by the corpus luteum and half by the placenta (Lebech, 1971).

We therefore investigated whether gestagens would exert effects on the placental $\Delta^{5}-3 \beta$-steroid dehydrogenase function similar to those obtained on luteal tissue in early pregnancy.

\section{Materials and Methods}

\section{Steroids}

The following synthetic gestagens were used: dydrogesterone (6-dehydro-retroprogesterone: Ferrosan, Malmö, Sweden); medroxyprogesterone ( $6 \alpha$-methyl-17 $\alpha$-acetoxyprogesterone: Medipolar Oy, Oulu, Finland); megoestrol (16 $\beta$-methyl-6-dehydro-17 $\alpha$-acetoxyprogesterone: Orion Oy, Helsinki, Finland); allyloestrenol (17 $\alpha$-allyl-4-oestren-17 $\beta$-ol: N. V. Organon, Oss, Holland);

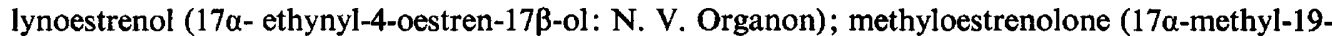
nortestosterone: N. V. Organon); norethisterone (17 $\alpha$-ethynyl-19-nortestosterone: Leiras, Turku, Finland); norethynodrel (17 $\alpha$-ethynyl-17 $\beta$-hydroxy-5(10)-oestren-3-one: Searle \& Co., Chicago, U.S.A.); and norgestrel (13 $\beta$-ethyl-17 $\alpha$-ethynyl-17 $\beta$-hydroxygon-4-en-3-one: Leiras). Pregnenolone and progesterone were obtained as commercial preparations from Sigma Chemical Co. (St Louis, U.S.A.). The purity of all these steroids was tested by thin-layer chromatography (t.l.c.) before use. 
$\left[4-{ }^{14} \mathrm{C}\right]$ Pregnenolone (sp. act. $51 \mathrm{mCi} / \mathrm{mmol}$ ) and $\left[4-{ }^{14} \mathrm{C}\right]$ progesterone (sp. act. $61 \mathrm{mCi} / \mathrm{mmol}$ ) were obtained from the Radiochemical Centre (Amersham, England). Their radiochemical purity was reported as $98 \%$ : t.l.c. tests in our laboratory showed them to be $96 \%$ and $98 \%$ pure, respectively.

All steroids were dissolved in ethanol-propyleneglycol solution $(1: 1 \mathrm{v} / \mathrm{v})$. Solvents were analytical grade and redistilled before use.

\section{Tissue and incubations}

Tissue from 26 placentae at 7-17 weeks of pregnancy, obtained at laparotomy in connection with legal abortions, was used. The period of gestation was calculated on the basis of the last menstrual period. A detailed description of the tissue preparation and the incubation procedure employed is given elsewhere (Saure, 1973). In brief, finely minced villous tissue was incubated as $500 \mathrm{mg}$ portions in $5 \mathrm{ml} 0.05 \mathrm{M}$-tris buffer medium ( $\mathrm{pH} \mathrm{7.4)}$ at $37^{\circ} \mathrm{C}$ and under continuous oxygen flow for $30 \mathrm{~min}$. Incubation was stopped by the addition of $2 \mathrm{ml}$ boiling acetone.

Control incubations. In 22 experiments the substrate was $\left[4-{ }^{14} \mathrm{C}\right]$ pregnenolone alone, in a dose of $0.145 \mu \mathrm{Ci}\left(=339 \times 10^{3}(\mathrm{ct} / \mathrm{min}) / 0.9 \mu \mathrm{g}\right)$ and at a concentration of $0.6 \mu \mathrm{mol} / 1$. Ten incubations in which the labelled substrate was diluted with different amounts $(10-500 \mu \mathrm{g}, 6 \cdot 2-310 \mu \mathrm{mol} / \mathrm{l})$ of unlabelled pregnenolone were also carried out.

Incubations with gestagens. In 44 experiments, $\left[4-{ }^{14} \mathrm{C}\right]$ pregnenolone (dose as in controls) was incubated with unlabelled progesterone or with a synthetic gestagen added in a concentration of 50 or $500 \mu \mathrm{g}$ per incubation. Each synthetic gestagen was also incubated in the absence of pregnenolone (100 $\mu \mathrm{g}$ gestagen/incubation). In 11 additional experiments labelled pregnenolone (dose as in controls) was diluted with different amounts of unlabelled pregnenolone (10-500 $\mu \mathrm{g})$ and incubated with equimolar concentrations of norethisterone or methyloestrenolone.

\section{Isolation and determination of radioactive steroids}

The methods used have been described previously (Suare, 1973; Saure et al., 1976). The radioactivity of the incubates was extracted in ether and the neutral and phenolic steroid fractions were separated. After sampling for liquid scintillation counting, the radioactivity contained in the neutral fraction was submitted to t.1.c. (chloroform:acetone: ethanol, 84:15:1 by vol.) and collected in four fractions. The most apolar of these contained progesterone which was quantified by the measurement of radioactivity and u.v.-absorption. When the progesterone fraction from different chromatograms of control incubations was pooled and studied in two-dimensional t.l.c. (ethylacetate:cyclohexane:ethanol, 9:9:1 by vol.) with authentic unlabelled progesterone as carrier, 94-98\% of the radioactivity was isolated in association with the carrier. Saure (1973) has shown that only progesterone in radiochemically homogeneous form can be eluted from the respective t.1.c. fractions of similar analyses, and more specific measures for the identification of the progesterone formed in the present incubations therefore seemed unnecessary.

The phenolic steroid fraction was not studied because earlier studies indicated that oestrogens were not formed in incubations of early placental tissue with pregnenolone (Saure, 1973). The recovery of $\left[4-{ }^{14} \mathrm{C}\right]$ progesterone was $89 \cdot 6-90 \cdot 3 \%$ after incubations with acetone-denatured tissue. The results presented are not corrected for the methodological losses.

\section{Results}

\section{Control incubations}

The mean ( \pm S.D.) recovery of radioactivity in the neutral steroid fraction was $85.3 \pm 5.0 \%$ of the dose, and $89 \cdot 1 \pm 4.2 \%$ (range: $75 \cdot 8-93.6 \%$ ) of this radioactivity was incorporated into the progesterone fraction. When pregnenolone was used at different concentrations the mean recovery of radioactivity in the neutral fraction was $90.9 \pm 3.2 \%$ of the dose. The progesterone formed in these incubations was measured both in terms of radioactivity incorporation and in $\mu \mathrm{g}$ by $\mathrm{u} . \mathrm{v}$.-absorption 
Table 1. The conversion of $\left[4 .{ }^{14} \mathrm{C}\right]$ pregnenolone $\left(339 \times 10^{3} \mathrm{ct} / \mathrm{min}=0.9\right.$ $\mu \mathrm{g}$ per incubation) to progesterone by human placental tissue of $7-12$ weeks in the presence of gestagens

\begin{tabular}{|c|c|c|c|}
\hline Gestagen & $\begin{array}{l}\text { Dose } \\
(\mu \mathrm{g})\end{array}$ & $\begin{array}{c}\text { No. of } \\
\text { incubations }\end{array}$ & $\begin{array}{c}\text { Progesterone } \\
\text { formation } \\
\text { (as \% of control) }\end{array}$ \\
\hline None & - & & 100 \\
\hline Progesterone & $\begin{array}{r}50 \\
500\end{array}$ & $\begin{array}{l}2 \\
2\end{array}$ & $\begin{array}{l}87 \cdot 5,89 \cdot 6 \\
80 \cdot 2,84 \cdot 1\end{array}$ \\
\hline Dydrogesterone & $\begin{array}{r}50 \\
500\end{array}$ & $\begin{array}{l}2 \\
2\end{array}$ & $\begin{array}{l}99 \cdot 3,101 \cdot 8 \\
95 \cdot 0,101 \cdot 5\end{array}$ \\
\hline $\begin{array}{l}\text { Medroxyprogesterone } \\
\text { acetate }\end{array}$ & $\begin{array}{r}50 \\
500\end{array}$ & $\begin{array}{l}2 \\
2\end{array}$ & $\begin{array}{l}93 \cdot 4,99 \cdot 1 \\
72 \cdot 1,81 \cdot 6\end{array}$ \\
\hline Megoestrol acetate & $\begin{array}{r}50 \\
500\end{array}$ & $\begin{array}{l}2 \\
2\end{array}$ & $\begin{array}{l}91 \cdot 7,88 \cdot 9 \\
67 \cdot 5,70 \cdot 3\end{array}$ \\
\hline Allyloestrenol & $\begin{array}{r}50 \\
500\end{array}$ & $\begin{array}{l}2 \\
2\end{array}$ & $\begin{array}{l}95 \cdot 5,102 \cdot 1 \\
96 \cdot 6,100 \cdot 9\end{array}$ \\
\hline Lynoestrenol & $\begin{array}{r}50 \\
500\end{array}$ & $\begin{array}{l}2 \\
2\end{array}$ & $\begin{array}{l}97 \cdot 7,97 \cdot 0 \\
98 \cdot 4,99 \cdot 8\end{array}$ \\
\hline Methyloestrenolone & $\begin{array}{r}50 \\
500\end{array}$ & $\begin{array}{l}2 \\
3\end{array}$ & $\begin{array}{l}60 \cdot 9,85 \cdot 2 \\
28 \cdot 0,23 \cdot 3,24 \cdot 5\end{array}$ \\
\hline Norethisterone & $\begin{array}{r}50 \\
500\end{array}$ & $\begin{array}{l}4 \\
3\end{array}$ & $\begin{array}{l}84 \cdot 7,82 \cdot 7,99 \cdot 2,99 \cdot 4 \\
38 \cdot 1,19 \cdot 9,20 \cdot 5\end{array}$ \\
\hline Norethynodrel & $\begin{array}{r}50 \\
500\end{array}$ & $\begin{array}{l}2 \\
2\end{array}$ & $\begin{array}{l}106 \cdot 6,100 \cdot 7 \\
105 \cdot 5,97 \cdot 0\end{array}$ \\
\hline Norgestrel & $\begin{array}{r}50 \\
500\end{array}$ & $\begin{array}{l}2 \\
2\end{array}$ & $\begin{array}{l}89 \cdot 6,97 \cdot 6 \\
69 \cdot 3,73 \cdot 9\end{array}$ \\
\hline
\end{tabular}

(sensitivity $=2 \mu \mathrm{g}$, precision $0.5 \mu \mathrm{g}$ ). The results obtained by these two procedures correlated well, indicating that radioactive and unlabelled pregnenolone were equally metabolized under the present experimental conditions. When $10,25,50,250$ or $500 \mu \mathrm{g}$ pregnenolone were added, the progesterone formed was $8 \mu \mathrm{g}(n$, no. of incubations, $=1), 18.5$ and $20 \mu \mathrm{g}(n=2), 32 \cdot 5 \mu \mathrm{g}(27 \cdot 5-38 ; n=5), 67 \mu \mathrm{g}$ $(n=1)$ and $64.5 \mu \mathrm{g}(n=1)$, respectively.

\section{Incubations with gestagens}

The mean ( \pm S.D.) total recovery of radioactivity in the neutral fraction was $81.7 \pm 4.6 \%$ of the dose. The capacity of the placental tissue to convert radioactive pregnenolone to progesterone in the presence of added progesterone or other gestagens is shown in Table 1.

In the presence of progesterone the rate of formation of radioactive progesterone was slightly reduced. There was little effect on the incorporation of radioactivity into progesterone when dydrogesterone, allyloestrenol, lynoestrenol or norethynodrel were added. When medroxyprogesterone acetate, megoestrol acetate, norgestrel or norethisterone were present at the lower concentration $(50 \mu \mathrm{g})$, the formation of radioactive progesterone was reduced slightly but no more so than in the presence of $50 \mu \mathrm{g}$ progesterone. The higher concentration of $500 \mu \mathrm{g}$ caused a reduction in progesterone formation. The most inhibitory of the gestagens tested were norethisterone and methyloestrenolone.

The results of incubations with equimolar concentrations of norethisterone and methyloestrenolone with pregnenolone are shown in Table 2.

\section{Discussion}

A major steroidogenic function of the placenta is the conversion of $\Delta^{5}$ - to $\Delta^{4}$-steroids (Diczfalusy, 1969). Labelled pregnenolone was almost quantitatively converted to progesterone in the control incubations of the present study, as found earlier with first trimester placentae (Saure, 1973). Placental 
Table 2. The conversion of pregnenolone incubated in different concentrations with human placental tissue of 11-12 weeks to progesterone in the presence of equimolar amounts of methyloestrenolone and norethisterone

\begin{tabular}{|c|c|c|c|c|c|}
\hline \multirow{3}{*}{$\begin{array}{l}\text { Pregnenolone }(\mu \mathrm{g}) \\
+ \text { gestagen }(\mu \mathrm{g})\end{array}$} & \multirow{3}{*}{$\begin{array}{c}\text { No. of } \\
\text { incubations }\end{array}$} & \multicolumn{4}{|c|}{ Progesterone formation } \\
\hline & & \multicolumn{2}{|c|}{ Methyloestrenolone } & \multicolumn{2}{|c|}{ Norethisterone } \\
\hline & & $\mu \mathrm{g}$ & $\%$ of control & $\mu \mathrm{g}$ & $\%$ of control \\
\hline $10+10$ & 1 & $7 \cdot 5$ & 93.8 & - & - \\
\hline $25+25$ & 4 & 10,12 & $54 \cdot 1,60 \cdot 0$ & $16,18 \cdot 5$ & $86 \cdot 5,92 \cdot 5$ \\
\hline $50+50$ & 4 & $8,11 \cdot 5$ & $29 \cdot 1,34 \cdot 0$ & $16 \cdot 5,21$ & $60 \cdot 0,62 \cdot 7$ \\
\hline $500+500$ & 2 & 18 & $27 \cdot 9$ & 27 & $41 \cdot 9$ \\
\hline
\end{tabular}

progesterone is mainly derived from maternal plasma cholesterol which is converted to pregnenolone in the placenta (Diczfalusy, 1969; Burstein \& Gut, 1971). At term the placenta contains a relatively large pool of cholesterol (Villee, VanLeusden \& Zelewski, 1966), but only a small portion of the pool contributes to progesterone synthesis in vitro. According to Maeyama, Tuchida \& Matuoka (1968), the net synthesis of progesterone from endogenous precursors in placental minces of 35-40 weeks was was $0.6-1.9 \mu \mathrm{g} / \mathrm{g}$ during incubation for $2 \mathrm{~h}$. The endogenous progesterone content of this tissue before incubation was $1 \cdot 1-2 \cdot 0 \mu \mathrm{g} / \mathrm{g}$. In the present incubations, therefore, the synthesis of progesterone from endogenous precursors probably had no influence on the incorporation of radioactivity in progesterone.

The present results confirm and extend our preliminary observations (Karjalainen, Saure \& Teräväinen, 1972) on the effect of gestagens on the placental $\Delta^{5}-3 \beta$-dehydrogenase activity in early pregnancy. It seems possible that dydrogesterone, allyloestrenol and norethynodrel might even stimulate the formation of progesterone in placental tissue. Allyloestrenol has been shown to increase the urinary pregnanediol excretion during pregnancy (Szontágh \& Sas, 1964) and to stimulate the conversion of radioactive pregnenolone to progesterone in term placental homogenates (Barlas $e t$ al., 1974).

Norgestrel and the 17 $\alpha$-acetoxyprogesterone derivatives used had an inhibitory effect comparable to that of progesterone. Norgestrel given in doses of $10 \mathrm{mg} /$ day in early pregnancy decreased plasma progesterone level in only one of three subjects treated (Nygren \& Johansson, 1975). Similar reports concerning $17 \alpha$-acetoxyprogesterone derivatives are not available.

Norethisterone and methyloestrenolone, both $\Delta^{4}-3-$ keto-19-nortestosterone derivatives, were the most inhibitory in the present incubations. The substitution of the 13-methyl group of norethisterone for an ethyl group as in norgestrel seemed to reduce the inhibitory activity. When a $17 \alpha-$ ethynyl group was substituted for $17 \alpha$-methyl, as in methyloestrenolone, the inhibitory effect was clearly enhanced (see Table 2). Methyloestrenolone was more inhibitory than norethisterone in all concentrations tested, even at a concentration of $15 \cdot 3 \mu \mathrm{mol} / 1$. Methyloestrenolone was also the most effective of these nine gestagens studied in reducing the in-vitro formation of progesterone in luteal tissue of early pregnancy (Saure et al., 1976).

It is known that HCG counteracts the inhibitory effect of some gestagens, including norethisterone, on progesterone synthesis in the corpus luteum of the menstrual cycle in vivo (Johansson, 1971). HCG is evidently present and possibly also synthesized by placental preparations during incubation. The addition of HCG, however, has no effect on the formation of progesterone from cholesterol and pregnenolone in placental tissue in vitro (Saure, 1973), even after neutralization of the endogenous HCG with a specific antiserum (Macome, Bischoff, Uma Bai \& Diczfalusy, 1972).

In vivo, however, the large amount of $\mathrm{HCG}$ present during early pregnancy may counteract the effect of gestagens, especially in the corpus luteum, thus explaining the finding that treatment of women, 35-56 days pregnant, with norethisterone resulted in only a transient decrease of the plasma progesterone (Nygren \& Johansson, 1975). 


\section{References}

Barlas, P., Adelung, K., Röhner, R., Weimer, A., Keller, E. \& Schindler, A.E. (1974) The effect of drugs on the steroid metabolism of the normal placenta. Acta endocr., Copenh., Suppl. 184, 35, Abstr.

Burstein, S. \& GuT, M. (1971) Biosynthesis of pregnenolone, Recent Prog. Horm. Res. 27, 303-349.

Collins, W.P., Koullapis, E.N., Ferguson, K.M., Biswas, S., Sharples, M.J. \& Sommerville, I.F. (1974) Effects of norethisterone on pituitary and ovarian function. Acta endocr., Copenh. 75, 357367.

Csapo, A.I., Pulkkinen, M.O., Ruttner, B., Sauvage, J.P. \& WIEST, W.G. (1972) The significance of the human corpus luteum in pregnancy maintenance. 1. Preliminary studies. Am. J. Obstet. Gynec. 112, 1061-1067.

DiczFalusy, E. (1969) Steroid metabolism in the foetoplacental unit. In The Foeto-Placental Unit, pp. 65109. Eds A. Pecile \& C. Finzi. Excerpta Medica, Amsterdam.

Johansson, E.D.B. (1971) Depression of the progesterone levels in women treated with synthetic gestagens after ovulation. Acta endocr., Copenh. 68, 779-792.

Karjalainen, O., Saure, A. \& TeräväInen, T. (1972) Effect of synthetic gestagens on progesterone formation in vitro in early human placenta. Scand. J. clin. Lab. Invest. 29, Suppl. 122, 41, Abstr.

LEBECH, P.E. (1971) Plasma levels of progesterone in early pregnancy after removal of the foeto-placental unit, and following removal of corpus luteum. Acta endocr., Copenh. Suppl. 155, 134, Abstr.

LehmanN, F., Just-Nastansky, I., Behrendt, B.,
Czygan, P.-J. \& BetTendorf, G. (1974) Influence of exogenous steroids on corpus luteum function. Acta endocr., Copenh., Suppl. 184, 152, Abstr.

Macome, J.C., Bischoff, K., Uma BaI, R. \& DiczFALUSY, E. (1972) Factors influencing placental steroidogenesis in vitro. Steroids 20, 469-485.

Maeyama, M., Tuchida, Y. \& MatuoKa, H. (1968) Progesterone metabolism in twins: progesterone biosynthesis in placenta in vitro. Steroids 11, 799-816.

MukherJee, T.K., Wright, S.W. \& Davidson, N.H.J. (1972) Effect of norgestrel on corpus luteum function. J. Obstet. Gynaec. Br. Commonw. 79, 175-182.

Nygren, K.G. \& Johansson, E.D.B. (1975) The effect of norethindrone and some other synthetic gestagens upon the peripheral plasma levels of progesterone and estradiol during early, human pregnancy. Acta obstet. gynec. scand. 54, 57-63.

Saure, A. (1973) The biogenesis and metabolism of steroids in the human placenta of 9-14 weeks in vitro. Annls Acad. sci. Fenn., Sect. V, Medica, 159, 1-131.

Saure, A., Karialainen, O. \& Teräväinen, T. (1976) The effect of synthetic gestagens on progesterone formation in vitro in human corpus luteum of early pregnancy. Eur. J. Obstet. Gynec., Reprod. Biol. 6, 223-234.

SzonTÁGH, F.E. \& SAS, M. (1964) Investigations into the influence of allylestrenol on placental steroid secretion. Magy. Nöorvos. Lap. 27, 323-328.

Villee, C.A., VanLeusden, H. \& Zelewski, L. (1966) The regulation of the biosynthesis of sterols and steroids in the placenta. In Advances in Enzyme Regulation, Vol. 4, pp. 161-179. Ed. G. Weber. Pergamon Press, Oxford.

Received 21 January 1977 